\title{
Okuduğunu Anlama Stratejilerinin Bilişsel ve Duyuşsal Öğrenme Ürünlerine Etkisi²
}

\author{
Prof. Dr. Özcan DEMIREL \\ Uluslararası Kıbrıs Üniversitesi, Lefkoşa, Kuzey Kıbrıs Türk Cumhuriyeti
}

Yrd. Doç. Dr. Cevdet EPÇAÇAN*

Siirt Üniversitesi, Eğitim Fakültesi, Siirt, Türkiye

\section{Özet}

Bu çalışmanın amacı, İTS ve TïÖD okuduğunu anlama stratejilerinin ilköğretim 5. sınıf öğrencilerinin bilişsel ve duyuşsal öğrenme düzeyleri üzerindeki etkilerini belirlemektir. Araştırmada kontrol gruplu ön test-son test deneysel desen modeli kullanılmıştır. Araştırmada nicel veri toplama araçlarından yararlanılmıştır. Araştırmanın verileri, Türkçe dersi bilişsel giriş davranışları testi, okuduğunu anlama testi, okuduğunu anlamaya ilişkin öz yeterlik algısı ölçeği ve Türkçe dersine yönelik tutum ölçeğinin uygulanmasıyla elde edilmiştir. Nicel verilerin analizinde SPSS

\footnotetext{
${ }^{2}$ Bu çalışma, Prof. Dr. Özcan DEMİREL danışmanlığında Cevdet EPÇAÇAN tarafindan hazırlanan “Okuduğunu Anlama Stratejilerinin Bilişsel ve Duyuşsal Öğrenme Ürünlerine Etkisi” başlıklı doktora tez çalışmasının bir bölümüdür.

* Sorumlu Yazar. Tel: +90 5052702652 E-posta: epcacan@gmail.com

(C) 2012 Kalem Eğitim ve Sağlık Hizmetleri Vakfı. Bütün Hakları Saklıdır. ISSN: 2146-5606
} 
paket programından yararlanılarak istatistiksel işlemler yapılmıştır. Nicel verilerden elde edilen sonuçlara göre, İTS ve TïÖD okuduğunu anlama stratejilerinin öğrencilerin okuduğunu anlama düzeylerinin artmasında, Türkçe dersine ilişkin tutumlarının olumlu yönde gelişmesinde, okuduğunu anlama öz yeterlik algılarının yükselmesinde daha etkili oldukları saptanmıştır.

Anahtar Kelimeler: Öğrenme stratejileri; Okuduğunu anlama; Öz yeterlik algısi; Tutum ölçeği.

\title{
Effects of Reading Comprehension Strategies on Cognitive and Affective Learning Outcomes
}

\begin{abstract}
The purpose of this study is to determine effects of Coop-Dis$\mathrm{Q}$ and POSSE reading comprehension strategies on 5. graders cognitive and affective levels. Pretest - posttest with control group experimental design model has been used in the research. Quantitative data collecting instruments were used in the research. Quantitative data obtained by administration of cognitive entry test for Turkish course, test of reading comprehension, self-efficacy belief scale for reading comprehension and attitude scale related to Turkish 1 course,. In the analysis of quantitative data statistical operations were performed by practicing SPSS packet program. Descriptive analysis was used in analyzing of qualitative data. According to results obtained from quantitative and qualitative data, Coop-Dis-Q and POSSE reading comprehension strategies has been more effective than conventional instruction in increasing level of reading comprehension, in developing attitudes related to Turkish course and in rising self- efficacy beliefs related to reading comprehension.
\end{abstract}

Keywords: Learning strategies; Reading comprehension; Self efficacy belief; Attitude scale. 


\section{Extended Summary}

Reading activity is an active process which improves human's knowledge capacity, shapes their beliefs and ideas and gains them identity. This process is an intellectual activity in which human's biological, psychological, physiological features work in harmony. There is "understanding” aim in substance of this activity.

It is important for a student to be active during prereading, reading and after reading to comprehend reading in a healthy way.

Reading comprehension strategies are used as a part of constructivist process which improves comprehension. Active readers use these strategies to construct meaning during prereading, reading and after reading. Furthermore, these strategies are methods contributing to be active, skillful, improving themselves, reading consciously and can be learned.

Cooperative Discussion and Questioning (Coop-Dis-Q) which has been developed by Lane Roy Gauthier (2001) who is an instructor in Houston University, whose main area is interested in reading comprehension and developing instructional strategies for readers, implemented to 5. grade students.

In Coop-Dis-Q strategies “Cooperation, Discussion and Interrogation” three of them are implemented together. The logic of reading comprehension is that one's difficulty increases the benefits of two others and thanks to it constituting a synergistic teaching area. 
Coop-Dis-Q reading comprehension strategies are processed step by step. The reason behind it that Coop-Dis-Q is a reading comprehension strategy which is intended to process learning together ,discussion and questioning one by one.

Predict, Organizing, Searching Summarization, Evaluation (POS$\mathrm{SE}$ ) reading comprehension strategy has been developed by Englert and Mariage (1991) to enable the students who have learning difficulties to remember their own knowledge. This composed reading strategy has been developed by Palincsar and Brown in 1985 to understand a reading passage by means of modeling step, mutual teaching which guides the students and integrated concept maps showing the meaning of words with using visual things (Mariage, 1995, s.216).

These researches have been made to determine the impacts of Coop-Dis-Q and POSSE reading comprehension strategies on student's cognitive (the level of reading comprehension) and sensual (self competence in reading comprehension, attitude to Turkish lesson). Pretest with controlling group-last test experimental model is used in these researches. To realize the search’s aims benefited from quantitive datum gathering devices. Quantitive datum of research has been gained with the implementing of reading comprehension test, self competence perception measure related to reading comprehension and attitude measure towards to Turkish lesson .As for qualitative datum, they have been gathered with the using of the forms which enable to determine student and teacher's opinion about learning and teaching process and using observation form which gives information about working of the process. Because of being 
used experimental pattern, cosmos and sample determination aren't used .The researches have been realized with the help of $5^{\text {th }}$ grade students of Siirt Mehmetçik Primary School attached to National Education Ministry.

Since in the research there are two empirical groups and one control group, for means of tests; reading comprehension test, attitude towards Turkish lesson test and the scale self-efficacy belief of reading comprehension applied to two empirical groups and one control group, one-way variance analyze has been used.

Experimental process implemented on both of the empirical groups Coop-Dis-Q and POSSE reading comprehension strategies gathered by statistical analysis on the quantitive datum can be said to have an positive impact on student's reading comprehension ability, attitude to Turkish lesson, reading comprehension self efficacy belief and ability to keep in mind reading.

Cooperative group workings, question -reply and discussion activities in Turkish lesson should take part to improve student's cognitive and sensual learning in a meaningful and desirable way. In Turkish lesson, before the students read the passage they should be encouraged to guess the topic of subject by looking pictures and visual things given with the passage. Before the passage isn't read, activities which improve the student's imagination should be made. The students should be diverted to use concept maps, visual figures and pictures while comprehending the reading passage. At the end of the reading comprehend activities, they are 
diverted to compose question and reply them to reinforce the understanding of the passage. The student should be encouraged to make summarization, grouping and organizing in other lessons such as science and technology, social studious apart from Turkish lesson. Coop-Dis-Q and POSSE reading comprehension strategies should take part among the strategies which recommended for Turkish lesson teaching program. Activities in Turkish lesson books should be rearranged according to them. Teacher should be informed about reading comprehension strategies especially Coop-Dis-Q and POSSE reading comprehension strategies.

\section{Giriş}

İnsanoğlu vâr olduğu günden bu yana varlığı, yaşamı, yaşadığı evrende olup biten olayları anlamaya, açıklamaya ve yorumlamaya çalışmaktadır. Bilimsel araştırmaların temel hareket noktası olan bu çaba, bir çeşit okuma ve anlama etkinliği olarak bütün hızıyla günden güne devam etmektedir. Okuma etkinliği, insanoğlunun bilgi kapasitesini artıran, düşünce ve inançlarına şekil veren, ona kişilik kazandıran etkin bir süreçtir. Bu süreç bireyin biyolojik, psikolojik, fizyolojik özelliklerinin etkin bir bütünlük içinde çalıştığı düşünsel bir etkinliktir. Okuma duyuş, etkileşim, algılama, deneyim, düşünme, öğrenme, çağrışım, etkileme ve yapılandırma süreçlerini kapsayan çok yönlü karmaşık bir süreçtir (Kent, 2002, s.22).

Okuma; başlangıcı, gelişim aşamaları ve sonucu olan bir süreç olarak tanımlanabilmektedir. Okuma esnasında anlamlandırılan sözcük ve cümleler sürekli belleğe yerleşmekte ve burada okuyucu ön bilgilerini de kullanarak ilgileri doğrultusunda bütünün anlamını elde etmeye çalış- 
maktadır. Elde edilen anlam, uzun süreli belleğe yönlendirilerek okuma ve anlama gerçekleşmektedir (Akyol, 2005).

Bullock (1975)'e göre okuma, öğrenme için başvurulan temel bir strateji olduğundan hemen hemen eğitimin her aşamasında ve türünde öğretmenlerin geliştirmeleri gereken bir beceridir (akt; Wellington and Osborne, 2001).

\section{Okuduğunu Anlama}

Okuduğunu anlama, yazılı bir materyalden anlam çıkarmayı ve ayrıntıları kavramayı gerektiren, daha ilköğretim düzeyinden itibaren öğrencilere kazandırılması gereken temel dil becerilerinden biridir (Rose ve ark., 2000). Okuduğunu anlama, hem metindeki bilgiler hem de okuyucunun yorumlarını kapsayan, yazarın vermek istediği mesajların mantıksal olarak yapılandırıldığı etkin bir süreç olarak tanımlanabilir (Radoyevic, 2006). Okuma sürecinin esas hedefi olan okuduğunu anlama, okuyucunun etkin ve bilinçli bilişsel çabasını gerektiren karmaşık bir süreç olarak betimlenir. Okuduğunu anlamada amaç, okuyucunun düşünce gelişimini inşa etmek, yapılandırmaktır (Block, 2004, s.2).

Okuduğunu anlama bir metindeki sözcük veya kavramları seslendirme veya ezberleme değildir; yazıya geçirilmiş, anlamlandırılmış sözcük, kavram, cümle, paragraf veya metinlere can verme, bunları algısal veya yargısal birtakım işlemlerden geçirerek işlevselleştirme, yeniden anlamlandırma işlemidir (Şengül ve Yalçın, 2004, s.39). Güneş’e (2004) göre okuduğunu anlama, yazının anlamını bulma, onlar üzerinde düşünme, nedenlerini araştırma, sonuçlar çıkarma ve değerlendirmeden ibaret 
olmakla birlikte; inceleme, seçim yapma, karara varma, çevirme, yorumlama, öteleme, analiz-sentez yapma ve değerlendirme gibi zihinsel faaliyetleri de içine almaktadır. Okuduğunu anlama, okuyucunun kendi bilgilerini yazarınkilerle karşılaştırması ve onun görüşlerinden kabul edip etmedikleri hakkında bir yargıya varmasıdır (Kantemir, 1995). Demirel ve Şahinel (2006), iki ayrı çaba gibi görünen "okuma" ve "anlama"nın aslında birbirine neden-sonuç ilişkisi ile bağlı olduğunu belirterek, anlayarak okumanın birinci aşamasını iyi okumak, ikinci aşamasını da yazıyı kavramak olarak gösterirler.

\section{Okuduğunu anlama stratejileri}

Öğrencilerin okuduğunu anlama kapasitelerini geliştirmenin, sınıf öğretmenlerinin esas bir uğraşı olduğunun farkında olan eğitmenler yıllarca bu amaca ulaşmak için birçok strateji, yöntem veya teknik önermiş, araştırmış, doğrulamış ve uygulamıştır. Öğrencinin okuduğunu sağlıklı bir biçimde anlayabilmesi için okuma öncesi, okuma sırası ve okuma sonrasında etkin olması, birçok strateji ve tekniği kullanabilmesi önemlidir.

Okuduğunu anlama stratejileri, anlamanın güçleştiği durumlarda, öğrencinin akademik konulardaki performansını geliştirebilen bilişsel araçlar olarak tanımlanır (Piloneita, 2006). Okuduğunu anlama stratejileri okuduğunu anlamayı geliştiren yapılandırmacı süreçlerin etkin bir parçası olarak kullanılır. Okuma süreci, rüzgârın toprak üzerindeki etkili esmesine benzer. Rüzgâr toprağın üzerindeki kiri ve tozu yalnızca toprak izin verdiği kadar kaldırır. Okunan bir metnin anlaşılması ve yorumlanması da ancak okuyucunun ön öğrenmeleri ve deneyimleri el verdiği ölçüde 
gerçekleşir (Pressley, 2001). Okuduğunu anlamayı artıran stratejiler dört ana başlık altında toplanabilir:

Tablo 1. Okuduğunu Anlama Stratejileri

\begin{tabular}{|c|c|}
\hline $\begin{array}{l}\text { Stratejinin İşe } \\
\text { Koşulduğu } \\
\text { Zaman }\end{array}$ & Stratejiler \\
\hline $\begin{array}{l}\text { Okuma Öncesi } \\
\text { Stratejiler }\end{array}$ & $\begin{array}{l}\text { - Okuma Amacını Açıklama } \\
\text { - Öğrenciye Parçanın Başlığına, Basım Tarihine, } \\
\text { Yazara Bakarak ve Parçayı Tarayarak Konusunu } \\
\text { Tahmin Etmesine Yardım Etme } \\
\text { - Başıı̆g Bak - İncele - Anahtar Sözcüklere Bak - } \\
\text { Okuma Parçasına Tekrar Bak - Öykü /Kavram } \\
\text { Haritası Hazırla (TELLS) } \\
\text { - Öğretim Öncesi Sözcük Bilgisi } \\
\text { - Kavram Haritaları ve Öykü Haritası Aracılığıyla } \\
\text { Kavramları Önceden Öğretme } \\
\text { - Okunacak Materyali Dikkatlice Seçme ve Bazı } \\
\text { Ölçütler Doğrultusunda Öğrencinin Okuma Parça- } \\
\text { sını Seçmesine İzin Verme }\end{array}$ \\
\hline $\begin{array}{l}\text { Okuma Sırası } \\
\text { Stratejiler }\end{array}$ & $\begin{array}{l}\text { - Akıcı ve Sürükleyici Okumayı Sağlama } \\
\text { - Öyküleyici Metinler İçin Öykü Haritasını Dikkate } \\
\text { Alma } \\
\text { - Açıklayıcı Okuma Parçaları İçin Taslaklar ve Ça- } \\
\text { lışma Rehberi Kullanma } \\
\text { - Açıklayıcı Metinler İçin Stratejik Not Almayı Uy- } \\
\text { gulama } \\
\text { - Açıklayıcı Metinler İçin Zaman Çizelgeleri ve } \\
\text { Akış Şemalarını Kullanma } \\
\text { - Karışı Planlar, Tablolar Yapma } \\
\text { - Öyküleyici Metinler İçin Görseller Kullanma }\end{array}$ \\
\hline
\end{tabular}




\begin{tabular}{|c|c|}
\hline $\begin{array}{l}\text { Okuma } \\
\text { Sonrası } \\
\text { Stratejiler }\end{array}$ & $\begin{array}{l}\text { - Her Türlü Metin İçin Özetleme Yapma } \\
\text { - Soru- Cevap İlişkisini Kullanma }\end{array}$ \\
\hline $\begin{array}{l}\text { Okuma } \\
\text { Sürecinin } \\
\text { Tümünde İşe } \\
\text { Koşulan } \\
\text { Stratejiler }\end{array}$ & $\begin{array}{l}\text { - Stratejik Not Alma } \\
\text { - GSOYBY: Gözleme, Sorma, Okuma, Yansıtma, } \\
\text { Bakmadan Cevaplama, Yeniden Gözden Geçirme } \\
\text { (SQ4R) } \\
\text { - } \text { Çoklu Geçiş Stratejisi (Multipass) } \\
\text { - Karşılıklı Öğretim (Reciprocal Teaching) } \\
\text { - Ne Biliyorum? Ne Öğrenmek İstiyorum? Ne Öğ- } \\
\text { rendim? (K-W-L) } \\
\text { - İşbirlikli Stratejik Okuma (Collaborative Strategic } \\
\text { Reading) } \\
\text { - Kavram Haritaları Ve Grafik Örgütlemeler (Con- } \\
\text { cept Map And Graphic Organizers) } \\
\text { - İTS Okuduğunu Anlama Stratejisi (Coop- Dis-Q) } \\
\text { - TïÖD Okuduğunu Anlama Stratejisi (POSSE) }\end{array}$ \\
\hline
\end{tabular}

Kaynak: (Daly, E.J. Chafouleas, S. Skinner ve C.H. 2005, s.112)

\section{ITS (İş birlikli tartışma sorgulama) okuduğunu anlama} stratejisi (coop-dis-q)

ITS, temel ilgi alanı okuduğunu anlama ve okuyucular için öğretimsel stratejiler geliştirmek olan Houston Üniversitesi öğretim üyelerinden Lane Roy Gauthier (2001) tarafından geliştirilmiş olup, ilköğretim 5. sınıf düzeyindeki öğrencilerle uygulanmıştır.

"İş birlikli, tartışma ve sorgulama" (İTS) stratejisinde her üç yöntem, birlikte uygulanmaktadır. Bu okuduğunu anlama stratejisinin mantığ1, birinin zorluğuna karşılık, diğer ikisinin faydasını arttırmak ve böylece sinerjik bir öğretim ortamı oluşturmaktır. 
Birçok araştırmacı tarafından İTS okuduğunu anlama stratejisinin gerekliliğine ilişkin görüşler dile getirilmiştir: Johnson, Johnson ve Holubee'a (1994) göre iş birlikli öğrenmeler, küçük öğretimsel gruplar arac1lığıyla öğrencilerin öğrenmelerini en yüksek düzeye çıkarmalarına yardımcı olur. Gambrel (1996), grup tartışmalarının, öğrencilerin okuma materyaline ilişkin hatırlama ve anlamalarını güçlendirdiğini saptamıştır. Strother'e (1989) göre sorgulama, okuduğunu anlamaya yardımcı olan öğretimsel kolaylaştırıcı bir tekniktir. İTS okuduğunu anlama stratejisi henüz yeni ve yalnız birkaç alanda test edilmiş olmasına karşın; iş birlikli öğrenme, tartışma ve sorgulama boyutlarının etkililiği birçok araştırma tarafindan desteklenmektedir (Bender ve Larkin, 2003). Okuduğunu anlamayı sağlamada etkili oldukları, çalışmalarla saptanmış değişik tekniklerin bütünleşik bir hâli olan İTS okuduğunu anlama stratejisinin öğrencilerin okuduğunu anlama becerilerinin gelişmesinde oldukça etkili olması beklenir.

ITTS okuduğunu anlama stratejisi adım adım işlenir. İTS'nin adım adım işlenişinin nedeni birlikte öğrenme, tartışma ve sorgulama sıralamasını işlemeye yönelik bir okuduğunu anlama stratejisi olmasıdır. Önce genel yönergeler sunulur, sonra adımların nasıl uygulandığı anlatılır. $\mathrm{Bu}$ stratejinin işlenişi aşağıda adımlar hâlinde verilmiştir:

Adım 1: Gruplar oluşturulur.

Adım 2: Birtakım Soru Hazırlanır.

Adım 3: Gruplar Öyküleri Tartışır, Soruları Bölüştürür.

Adım 4: Gruplar Tartışır, Soruları Cevaplar ve Yeni Sorular Ekler.

Adım 5: Gruplar Cevaplarını Sunar ve Tartışıllar. 


\section{TiÖD (=Tahmin - inceleme - özetleme - örgütleme - değerlendirme)} okuduğunu anlama stratejisi (POSSE)

TíÖD (Tahmin, İnceleme, Özetleme, Örgütleme, Değerlendirme) okuduğunu anlama stratejisi Englert ve Mariage (1991) tarafindan öğrenme yetersizliği yaşayan öğrencilere açıklayıcı metinlerde kendi bilgilerini hatırlamalarını sağlamak amacıyla geliştirilmiştir. Bu strateji, Palincsar ve Brown (1985) tarafından geliştirilen bir okuma parçasını anlamada modelleyici adımlar aracılığıyla öğrencilere rehberlik eden karşılık11 öğretim ile sözcüklerin anlamını görsellerle sunan kavram haritalarıyla birleştirilmiş karma bir okuma stratejisidir (Mariage, 1995). TİÖD okuduğunu anlama stratejisi, tematik metinleri (açıklayıcı, betimleyici, öyküleyici metinler) anlamada etkili bir okuduğunu anlama stratejisi örneği olarak kullanılır. TïÖD genellikle "model olma" ve "rehberlik etme” öğretme yöntemleriyle öğretilir. Bu stratejinin ilk aşamasında öğrenciler okuyacakları metni gözden geçirip tararlar. Böylece metnin içeriği, konusu hakkında kendi ön bilgilerinden de yararlanarak tahminlerde bulunurlar. Tahminlerini, düşüncelerini metnin yapısına uygun bir şekilde örgütler ve organize ederler. Bu örgütleme kavram haritaları, gruplamalar kullanılarak yapılabilir. Öğrenciler metni okumaya başlayarak metnin yapısı, içeriği ve ipuçlarını incelerler. Parçayı anlamayı sağlamak için sorucevap yoluyla öğretmenin hazırlamış olduğu sorulara cevap verirler. Okumadan sonra veya okuma aralarında, öğrenciler konuyla ilgili ana düşünceleri, yan düşünceleri, metinde geçen olayları özetlerler. Özetlemeler önce sözlü, sonra da yazılı olarak yapılır. Öğrenciler metne yönelik kavramalarını değişik kavram haritalarıyla, görsel şekil veya tablolarla örgütleme yoluna giderler. Öğrenciler özetleme ve örgütleme etkinlikle- 
rini kolaylaştırmak için soru oluşturmaya teşvik edilirler. Oluşturulan yeni sorular sınıfça yanıtlanır. Son olarak öğrenciler okudukları metne ilişkin kavramalarını;

a. Yaptıkları özetlemeleri, tahmin aşamasındaki etkinliklerle karşılaştırarak,

b. Özetleme aşamasında anlaşılmayan noktalara açıklık getirmek için yanıtlanan ve oluşturulan sorularla,

c. İleriye dönük yorum, tahmin ve düşüncelerini açıklayarak dĕgerlendirirler. İleriye dönük düşüncelerini metindeki ipuçlarından veya yeniden düzenlenen kavram haritalarından yararlanarak şekillendirebilirler.

Okuduğunu anlama ile Türkçe dersine yönelik tutumlar arasındaki ilişki

Tutumlar bireyin davranışları hakkında lehte veya aleyhte yorumlamaların yapılabilmesine ve bireyin de çevresine olumlu veya olumsuz tepkilerde bulunmasına kaynaklık eden eğilimler olarak da görülmektedir. Bireyin sergilemiş olduğu tutum, bir kişiye, sosyal gruba, kuruma, durum veya düşünceye karşı olabilir (Turgut, 1984). Bu tanımın içinde öğrencilerin herhangi bir derse karşı göstermiş olduğu tepkiler de yer almaktadır. Okulda öğrencilere istendik davranış, bilgi ve becerilerin kazandırılmasına aracılık eden tüm derslere olduğu gibi Türkçe dersine karŞı da öğrenciler hem bilişsel, hem de duyuşsal tepkiler geliştirirler. Öğrenci tutumu olarak nitelendirilebilecek olan bu tepkilerin olumlu veya olumsuz olması farklı değişkenlerden etkilenmektedir. Bu değişkenlerden bir tanesi olarak sayılabilecek okuduğunu anlama stratejileri öğrencilerin 
Türkçe dersine ve okumaya karşı olumlu tepkiler geliştirmelerine ve bu olumlu tepkiler sonucu derslerde daha fazla başarılı olmalarına katkı sağladığı söylenebilir. Nitekim Yaman (1999) ve Çakıcı (2007) yapmış oldukları araştırmada okuduğunu anlama stratejilerinin öğrencilerin Türkçe dersine ve okumaya karşı olumlu tepkiler geliştirmelerine katkı sağladığını belirlemişlerdir.

\section{Okuduğunu anlama ile öz yeterlik algısı arasındaki ilişki}

Okuduğunu anlamlandırabilen ve yorumlayabilen öğrencilerin okumaya ilişkin alışkanlıkları ve okuduğunu anlamaya dair kendilerine olan güvenleri, diğer bir deyişle; okuduğunu anlama öz yeterlik algıları da gelişmektedir.

Okuduğunu anlama öz yeterlik algısının olumlu yönde gelişmesinde öğrenme stratejilerinin, dolayısıyla okuduğunu anlama stratejilerinin de oldukça önemli bir etkisi olduğunu söylemek mümkündür. Çünkü bir stratejiyi başarılı bir biçimde kullanarak bir görevi yerine getirmek, bireyde öğrenmeye dönük davranışlarını kontrol edebilme duygusu sağlar. Strateji başarılı bir biçimde kullanılırsa, öğrencinin öz yeterlik algısı da gelişir ve o stratejiyi tekrar tekrar kullanmak ister. Bu durumda öğrenme stratejilerinin kullanımıyla, öğrenme ve okuduğunu anlama öz yeterlik algısının gelişimi arasında olumlu yönde anlamlı bir ilişki olduğu söylenebilir (Stroud, 2006). Harris’e (1982) göre öz yeterlik, öğrenmeyi artıran güdüsel bir yapıdır (akt; Durham, 2006). Sonuç olarak, öz yeterlik kavramı, öğrencilere öğretildiği zaman, öğrencilerde önemli bir etkiye sahip olan, öğrencilerin okuduğunu anlama becerilerinin önemli bir ölçüde ge- 
lişmesine katkı sağlayan dikkate değer bir değişken olarak kabul edilmelidir.

\section{Yöntem}

$\mathrm{Bu}$ araştırma İTS ve TIÖD okuduğunu anlama stratejilerinin öğrencilerin bilişsel (okuduğunu anlama düzeyi) ve duyuşsal (okuduğunu anlamaya ilişkin öz yeterlik algısı ve Türkçe dersine ilişkin tutum) öğrenme ürünlerine etkilerini belirlemek amacıyla yapılmıştır. Bundan ötürü bu araştırma öğrencilerin bilişsel ve duyuşsal öğrenme becerilerinin gelişimine katkı sağlayan İTS ile TİÖD okuduğunu anlama stratejilerinin uygulandığı öncü bir çalışma niteliğindedir. Aynı zamanda okuduğunu anlama stratejileri hakkında genel bir bilgi vermeyi amaçlamış olmasından dolayı alana katkı sağlayacağı umulmaktadır.

Araştırmanın amacı doğrultusunda İTS ve TİÖD okuduğunu anlama stratejilerinin öğrencilerin okuduğunu anlama erişileri, Türkçe dersi tutum erişileri ve okuduğunu anlama öz yeterlik algısı erişileri üzerinde olumlu etkilerinin olup olmadığı saptanmaya çalışılmıştır. Bunun için de araştırmada kontrol gruplu ön test - son test deneysel modeli kullanılmıştır. Çünkü bu model, daha önce oluşmuş grupların aynen alınmış olduğu deney ve kontrol gruplarının şans yoluyla (random) atandığı, grupların bir kez deney başlamadan önce, bir kez de deney bittikten sonra ölçüldüğü esasına dayanır (Kaptan, 1998). Araştırmanın amaçlarını gerçekleştirmek için nicel veri toplama araçlarından yararlanılmıştır. Araştırmanın nicel verileri; okuduğunu anlama testi, okuduğunu anlamaya ilişkin öz yeterlik algısı ölçeği ve Türkçe dersine yönelik tutum ölçeğinin uygulanmasıyla elde edilmiştir. 


\section{Veri Toplama Araçları}

Uzman görüşleri doğrultusunda test yönerge ve sorularında gerekli düzenlemeler yapıldıktan sonra 59 soruluk okuduğunu anlama testinin ön denemesi Mehmetçik İlköğretim Okulu 4. ve 6. sınıf öğrencileriyle gerçekleştirilmiştir. Ön deneme sonuçları üzerinde ITEMAN ile madde ve test istatistik analizleri yapılmıştır. Madde ve test istatistiklerinin belirlenmesiyle madde güçlük indeksi 0.30 ve üzerindeki maddeler seçilerek nihai test oluşturulmuştur. Soru maddelerinin madde güçlük indeksinin 0.31-0.84 arasında değiştiği görülmüştür. Maddelerin seçiminde madde güçlükleri düşük, orta ve yüksek maddelerin eşit dağılmasına ve nihai testin ortalama güçlüğünün çoğunlukla 0.50 civarında olmasına dikkat edilmiştir. Madde güçlük indeksi 0.30'un altında olan 11 soru maddesi atılmıştır. Okuduğunu anlama testinin KR-20 güvenirlik katsayısı 0.91, madde güçlük indeksinin ortalaması da 0,51 bulunmuştur.

Okuduğunu anlama öz yeterlik algısını ölçmek için okuduğunu anlama becerisi ile öz yeterlik ilişsisine yönelik kuramsal kaynaklardan yararlanılarak yeni bir ölçek geliştirme çalışması yapılmıştır Hazırlanan bu ölçekte 35 soru maddesi yer almıştır. Ölçek maddeleri; "Hiç Emin Değilim”, “Çok Az Eminim”, "Biraz Eminim”, “Oldukça Eminim”, “Tamamen Eminim” beşli likert tipinde düzenlenmiştir. Ölçeğin geliştirilmesinde uzman görüşlerinden yararlanılmıştır. Ölçeğin pilot uygulaması için Sïrt ilindeki farklı sosyo-ekonomik ve kültürel çevrelerde bulunan 9 ilköğretim okulunun 5. sınıf öğrencilerine uygulanmıştır. Toplam 521 öğrenciden ölçeği eksik dolduranlar elendikten sonra 500 öğrenciden yararlanılmıştır. 
Ölçeğin yapı geçerliği faktör analizi ile ortaya konmuştur. Faktör analizi yapılmadan önce verilerin faktör analizine uygunluğu KMO ve Bartlett Sphericity testiyle belirlenmiştir. Çünkü veriler üzerinde faktör analizinin yapılabilmesi için KMO değerinin en az 0.60 olması ve Bartlett Sphericity testinin anlamlı çıkması önerilmektedir (Büyüköztürk, 2004, s.120). KMO Testi değeri 0.918; Bartlett Sphericity testi değeri $2829.90(\mathrm{p}=0.000<0.05)$ olarak bulunmuştur. $\mathrm{Bu}$ da verilerin faktör analizi için uygun olduğunu göstermiştir. Ölçeğin yapı geçerliliğini belirlemek amaciyla yapılan tekrarlı faktör analizleri sonucunda 35 maddeden oluşan ölçekten, faktör yükü 0.35 'in altında olan maddeler atılmış, 27 maddeden oluşan ve üç faktörde toplanan bir ölçek yapısına ulaşılmıştır. Tüm maddelerin faktör yük değerlerinin 0.35 ile 0.74 arasında olduğu saptanmıştır. Açıklanan kümülatif varyans oranı \%51,16 olarak bulunmuştur. Ölçeğin toplam faktör yükünün de 34.31 düzeyinde olup 3 faktörden oluştuğu saptanmıştır. Faktör yükü 0.350 'nin altında olan ölçek maddeleri atıldıktan sonra 27 maddelik esas ölçeğin güvenirlik katsayısı ise 0.88 bulunmuştur.

Öğrencilerin deneysel çalışma öncesi ve sonrası Türkçe derslerine ilişkin tutumlarını belirlemek için tutum ölçeğinden yararlanılmıştır. Tutum ölçeği olarak Demirel (2002) tarafından geliştirilen “Türkçe Dersine İlişkin Tutum Ölçeği” kullanılmıştır. Kapsam geçerliği uzman kanılarıyla belirlenen ölçeğin cronbach alpha güvenirlik katsayısı 0.85 bulunmuştur.

Araştırma MEB'e bağl1, Siirt Mehmetçik İlköğretim Okulu'nun 5. sınıf öğrencileriyle gerçekleştirilmiştir. Mehmetçik İlköğretim Okulu, hem 3 tane 5. sınıfi olmasından hem tüm 5. sınıf öğretmenlerinin araştır- 
manın deneysel çalışmasına karşı olumlu bir tutuma sahip olmalarından ve iş birliğine açık olmalarından dolayı seçilmiştir. Araştırmada 3 tane 5. sınıftan yararlanılmıştır. Deneysel desen kullanıldığından çalışma gruplar1 rastgele belirlenmiştir. 1. deney grubunda İTS Okuduğunu Anlama Stratejisi, 2. deney grubunda TİÖD Okuduğunu Anlama Stratejisi doğrultusunda etkinlikler düzenlenmiş, diğer 5. sınıf ise kontrol grubu olarak belirlenmiştir.

Deneysel çalışma, hem deney gruplarında hem de kontrol grubunda "Sağlık ve Çevre" teması esas alınarak 6 haftalık bir deney süreci ile gerçekleştirilmiştir. 1. deney grubunda İTS, 2. deney grubunda TIÖD Okuduğunu Anlama Stratejisi uygulanmıştır. Kontrol grubunda ise, normal ders programındaki etkinlikler izlenmiştir. Deney sürecinin başında tüm gruplara "Sağlık ve Çevre" temasıyla bağlantılı bir "Okuduğunu Anlama Testi”, “Türkçe Dersi Tutum Ölçeği”, “Okuduğunu Anlama Öz Yeterlik Algısı Ölçeği” ön test olarak verilmiştir. Deney sürecinin sonunda da aynı testler tüm gruplara son test olarak uygulanmıştır. Araştırmanın bitiminden 5 hafta sonra da öğrencilere "Okuduğunu Anlama Testi” kalıcılık testi olarak uygulanmıştır.

\section{Verilerin Çözümlenmesi}

Deney grupları ile kontrol grubu öğrencilerinin okuduğunu anlama testi, Türkçe dersine yönelik tutum testi ve okuduğunu anlama öz yeterlik algısı ölçeği erişi ortalamaları için araştırmada iki deney ve bir kontrol grubu yer aldığından tek yönlü varyans analizine başvurulmuştur. 


\section{Bulgular ve Yorum}

\section{Birinci Denenceye İlişkin Bulgular ve Yorum}

Araştırmanın birinci denencesi "Deney grupları ile kontrol grubu öğrencilerinin okuduğunu anlama erişi puan ortalamaları arasında deney grupları lehine anlamlı bir fark vardır.” şeklindedir.

Tablo 2. Deney Grupları İle Kontrol Grubu Öğrencilerinin Okuduğunu Anlama Öntest-Sontest ve Erişi Puan Ortalamaları

\begin{tabular}{cccc}
\hline $\begin{array}{c}\text { Okuduğunu } \\
\text { Anlama Testi }\end{array}$ & $\begin{array}{c}\text { Deney } \\
\text { Grubu 1 }\end{array}$ & $\begin{array}{c}\text { Deney } \\
\text { Grubu 2 }\end{array}$ & Kontrol Grubu \\
\hline Öntest & 32,71 & 32,92 & 31,47 \\
\hline Sontest & 39,21 & 40,47 & 35,63 \\
\hline Erişi & 6,50 & 7,55 & 4,15 \\
\hline
\end{tabular}

Tablo 3. Okuduğunu Anlama Testi Erişi Puan Ortalama ve Standart Sapmaları

\begin{tabular}{cccc}
\hline Gruplar & $\mathbf{N}$ & $\bar{X}$ & Ss \\
\hline Deney Grubu 1 & 38 & 6,50 & 2,60 \\
\hline Deney Grubu 2 & 38 & 7,55 & 3,82 \\
\hline Kontrol Grubu & 38 & 4,15 & 5,00 \\
\hline
\end{tabular}

Tablo 3'te görüldüğü gibi okuduğunu anlama testi erişi puanı en yüksek olan grup deney grubu 2'dir. Ardından deney grubu 1'in puanı gelmektedir. Kontrol grubundaki öğrencilerin okuduğunu anlama erişi puan ortalamaları her iki deney grubunun erişi puan ortalamalarından anlamlı bir şekilde düşük çıkmıştır. 
Tablo 4. Deney Grupları İle Kontrol Grubu Öğrencilerinin Okuduğunu Anlama Testi Erişi Puan Ortalamalarının Tek Yönlü Varyans Analizi

\begin{tabular}{|c|c|c|c|c|c|c|}
\hline $\begin{array}{l}\text { Varyansın } \\
\text { Kaynağı }\end{array}$ & $\begin{array}{l}\text { Kareler } \\
\text { Toplamı }\end{array}$ & $\begin{array}{l}\text { Serbestlik } \\
\text { Derecesi }\end{array}$ & $\begin{array}{l}\text { Kareler } \\
\text { Ortalaması }\end{array}$ & $\mathbf{F}$ & $\mathbf{P}^{*}$ & $\begin{array}{c}\text { Farkın } \\
\text { Kaynağı } \\
\text { (TUKEY } \\
\text { HSD) } \\
\end{array}$ \\
\hline $\begin{array}{c}\text { Gruplar } \\
\text { arası }\end{array}$ & 229,49 & 2 & 114,74 & 7.4 & 0.001 & $\begin{array}{c}\text { DG1 - } \\
\text { Kontrol } \\
\text { DG2 - } \\
\text { Kontrol }\end{array}$ \\
\hline Gruplar içi & 1719,94 & 111 & 15,49 & & & \\
\hline Toplam & 1949,43 & 113 & & & & \\
\hline
\end{tabular}

Analiz sonuçlarına göre okuduğu anlama erişi puan ortalamaları bakımından gruplar arasında anlamlı farklılıklar $(\mathrm{p}=0.001)$ olduğu belirlenmiştir. Hangi gruplar arasında fark olduğunu belirlemek için de TUKEY HSD testine başvurulmuştur. $\mathrm{Bu}$ analiz sonucuna göre de deney grubu 1 ile kontrol grubu arasinda $(\mathrm{p}=0.029<0.05)$ deney grubu 1 lehine; deney grubu 2 ile kontrol grubu arasinda $(\mathrm{p}=0.001<0.05)$ deney grubu 2 lehine anlamlı bir farklılık olduğu görülmüştür. Analiz sonuçlarına göre, İTS ve TİÖD okuduğunu anlama stratejileri doğrultusunda işlenen Türkçe ders etkinliklerinin öğrencilerin okuduğunu anlama erişileri üzerinde olumlu bir etkiye sahip olduğu söylenebilir.

\section{İkinci Denenceye İlişkin Bulgular ve Yorum}

Çalışmanın ikinci denencesi "Deney grupları ile kontrol grubu öğrencilerinin Türkçe dersi tutum erişi puan ortalamaları arasında deney grupları lehine anlamlı bir fark vardır." şeklindedir. 
Tablo 5. Deney Grupları İle Kontrol Grubu Öğrencilerinin Türkçe Dersi Tutum Ölçeği Öntest, Sontest ve Erişi Puan Ortalamaları

\begin{tabular}{cccc}
\hline $\begin{array}{c}\text { Türkçe Dersi } \\
\text { Tutum Ölçeği }\end{array}$ & $\begin{array}{c}\text { Deney } \\
\text { Grubu 1 }\end{array}$ & $\begin{array}{c}\text { Deney } \\
\text { Grubu 2 }\end{array}$ & $\begin{array}{c}\text { Kontrol } \\
\text { Grubu }\end{array}$ \\
\hline Öntest & 126,13 & 114,65 & 126,86 \\
\hline Sontest & 139,23 & 135,73 & 113,18 \\
\hline Erişi & 13,10 & 21,07 & $-13,68$ \\
\hline
\end{tabular}

Tablo 5'te görüldüğü gibi deney grubu 1 ön testte 126,13 puan alırken, deney grubu 2 114,65 ve kontrol grubu da 126,86 ortalama puan almıştır. Son testte deney grubu 1 139,23 puan, deney grubu 2 135,73 puan ve kontrol grubu 113,18 puan almıştır.

Tablo 6. Türkçe Dersi Tutum Ölçeği Erişi Puanı Ortalama ve Standart Sapmalar1

\begin{tabular}{cccc}
\hline Gruplar & N & $\bar{X}$ & Ss \\
\hline Deney Grubu 1 & 38 & 13,10 & 16,62 \\
\hline Deney Grubu 2 & 38 & 21,07 & 24,54 \\
\hline Kontrol Grubu & 38 & $-13,68$ & 22,06 \\
\hline
\end{tabular}

Tablo 7. Deney Grupları İle Kontrol Grubu Öğrencilerinin Türkçe Dersi Tutum Erişi Puan Ortalamalarının Tek Yönlü Varyans Analizi

\begin{tabular}{ccccccc}
\hline $\begin{array}{c}\text { Varyansın } \\
\text { Kaynağı }\end{array}$ & $\begin{array}{c}\text { Kareler } \\
\text { Toplamı }\end{array}$ & $\begin{array}{c}\text { Serbestlik } \\
\text { Derecesi }\end{array}$ & $\begin{array}{c}\text { Kareler } \\
\text { Ortalaması }\end{array}$ & $\mathbf{F}$ & $\mathbf{P} *$ & $\begin{array}{c}\text { Farkın } \\
\text { Kaynağı } \\
\text { (TUKEY } \\
\text { HSD) }\end{array}$ \\
\hline $\begin{array}{c}\text { Gruplar } \\
\text { arası }\end{array}$ & 25203,28 & 2 & 12601,64 & 27.68 & 0.0 & $\begin{array}{c}\text { DG1 - } \\
\text { Kontrol } \\
\text { DG2 - } \\
\text { Kontrol }\end{array}$ \\
\hline $\begin{array}{c}\text { Gruplar } \\
\text { içi }\end{array}$ & 50532,55 & 111 & 455,24 & & \\
\hline Toplam & 75735,83 & 113 & & & \\
\hline p $<0.05$ & & & & &
\end{tabular}


Analiz sonuçlarına göre Türkçe dersine ilişkin tutum erişi puan ortalamaları bakımından gruplar arasında anlamlı farklılıklar $(\mathrm{p}=0.00)$ olduğu belirlenmiştir. Hangi gruplar arasında fark olduğunu belirlemek için de TUKEY HSD testine başvurulmuştur. Bu analiz sonucuna göre de öğrencilerin tutum ölçeği erişi puan ortalamaları bakımından deney grubu 1 ile kontrol grubu arasinda ( $\mathrm{p}=0.000<0.05)$ deney grubu 1 lehine; deney grubu 2 ile kontrol grubu arasında $(\mathrm{p}=0.000<0.05)$ deney grubu 2 lehine anlamlı bir farklılık olduğu görülmüştür.

Veriler üzerinde yapılan istatistiksel analizlere dayalı olarak elde edilen bulgulardan hareketle; her iki deney grubunda işe koşulan İTS ve TİÖD okuduğunu anlama stratejilerinin öğrencilerin Türkçe dersine karş1 olumlu tutum geliştirmeleri konusunda olumlu katk1 sağladığı söylenebilir.

\section{Üçüncü Denenceye İlişkin Bulgular ve Yorum}

Araştırmanın üçüncü denencesi, "Deney grupları ile kontrol grubu öğrencilerinin öz yeterlilik algısı erişi puan ortalamaları arasında deney grupları lehine anlamlı bir fark vardır." şeklindedir.

Tablo 8. Deney Grupları İle Kontrol Grubu Öğrencilerinin Okuduğunu Anlama Öz Yeterlik Algısı Ölçeği Öntest, Sontest ve Erişi Puanı Ortalamalar1

\begin{tabular}{cccc}
\hline $\begin{array}{c}\text { Okuduğunu Anlama } \\
\text { Ozz Yeterlik Algısı Ölçeği }\end{array}$ & $\begin{array}{c}\text { Deney } \\
\text { Grubu 1 }\end{array}$ & $\begin{array}{c}\text { Deney } \\
\text { Grubu 2 }\end{array}$ & $\begin{array}{c}\text { Kontrol } \\
\text { Grubu }\end{array}$ \\
\hline Öntest & 109,86 & 103,86 & 115,10 \\
\hline Sontest & 120,10 & 116,68 & 116,47 \\
\hline Erişi & 10,24 & 12,18 & 1,37 \\
\hline
\end{tabular}


Tablo 9. Okuduğunu Anlama Öz Yeterlik Algısı Ölçeği Erişi Puan Ortalama ve Standart Sapmaları

\begin{tabular}{cccc}
\hline Gruplar & N & $\bar{X}$ & Ss \\
\hline Deney Grubu 1 & 38 & 10,24 & 13,05 \\
\hline Deney Grubu 2 & 38 & 12,18 & 14,35 \\
\hline Kontrol Grubu & 38 & 1,37 & 13,90 \\
\hline
\end{tabular}

Tablo 10. Deney Grupları İle Kontrol Grubu Öğrencilerinin Okuduğunu Anlama Öz Yeterlik Algısı Erişi Puan Ortalamalarının Tek Yönlü Varyans Analizi

\begin{tabular}{|c|c|c|c|c|c|c|}
\hline $\begin{array}{l}\text { Varyansın } \\
\text { Kaynağı }\end{array}$ & $\begin{array}{l}\text { Kareler } \\
\text { Toplamı }\end{array}$ & $\begin{array}{c}\text { Serbestlik } \\
\text { Derecesi }\end{array}$ & $\begin{array}{c}\text { Kareler } \\
\text { Ortalaması }\end{array}$ & $\mathbf{F}$ & $\mathbf{P}^{*}$ & $\begin{array}{c}\text { Farkın } \\
\text { Kaynağı } \\
\text { (TUKEY } \\
\text { HSD) } \\
\end{array}$ \\
\hline $\begin{array}{l}\text { Gruplar } \\
\text { aras1 }\end{array}$ & 2740,33 & 2 & 1370,16 & 7.21 & 0.001 & $\begin{array}{c}\text { DG1 - } \\
\text { Kontrol } \\
\text { DG2 - } \\
\text { Kontrol }\end{array}$ \\
\hline $\begin{array}{c}\text { Gruplar } \\
\text { içi }\end{array}$ & 21079,42 & 111 & 189,90 & & & \\
\hline Toplam & 23819,75 & 113 & & & & \\
\hline
\end{tabular}

Analiz sonuçlarına göre okuduğu anlama öz yeterlik algısı erişi puan ortalamaları bakımından gruplar arasında anlamlı farklılıklar ( $p=0.001)$ olduğu belirlenmiştir. Hangi gruplar arasında fark olduğunu belirlemek için de TUKEY HSD testine başvurulmuştur. Bu analiz sonucuna göre deney grubu 1 ile kontrol grubu arasında $(p=0.016<0.05)$ deney grubu 1 lehine; deney grubu 2 ile kontrol grubu arasinda $(p=0.001<0.05)$ deney grubu 2 lehine, okuduğunu anlama öz yeterlik 
algısı erişi puan ortalamaları bakımından anlamlı farklılıklar olduğu görülmüştür.

\section{Dördüncü Denenceye İlişkin Bulgular ve Yorum}

Araştırmanın dördüncü denencesi, “Deney grupları ile kontrol grubu öğrencilerinin okuduğunu anlama kalıcılık puan ortalamaları arasında deney grupları lehine anlamlı bir fark vardır.” şeklindedir.

Tablo 11. Deney Grupları İle Kontrol Grubu Öğrencilerinin Okuduğunu Anlama Kalıcılık Testi Puan Ortalama ve Standart Sapmaları

\begin{tabular}{cccc}
\hline Gruplar & N & $\bar{X}$ & Ss \\
\hline Deney Grubu 1 & 37 & 39,51 & 4,98 \\
\hline Deney Grubu 2 & 38 & 40,71 & 6,50 \\
\hline Kontrol Grubu & 38 & 34,73 & 9,13 \\
\hline
\end{tabular}

Tablo 12. Deney Grupları İle Kontrol Grubu Öğrencilerinin Okuduğunu Anlama Kalıcılık Testi Puan Ortalamaları Tek Yönlü Varyans Analizi

\begin{tabular}{ccccccc}
\hline $\begin{array}{l}\text { Varyansın } \\
\text { Kaynağı }\end{array}$ & $\begin{array}{c}\text { Kareler } \\
\text { Toplamı }\end{array}$ & $\begin{array}{c}\text { Serbestlik } \\
\text { Derecesi Ortalaması }\end{array}$ & $\begin{array}{c}\text { Kareler } \\
\text { F }\end{array}$ & $\mathbf{P}^{*}$ & $\begin{array}{c}\text { Farkın } \\
\text { Kaynağı } \\
\text { (TUKEY } \\
\text { HSD) }\end{array}$ \\
\hline $\begin{array}{c}\text { Gruplar } \\
\text { aras1 }\end{array}$ & 757,73 & 2 & 378,86 & 7.51 & 0.001 & $\begin{array}{c}\text { DG1 - } \\
\text { Kontrol } \\
\text { DG2 - } \\
\text { Kontrol }\end{array}$ \\
\hline $\begin{array}{c}\text { Gruplar } \\
\text { içi }\end{array}$ & 5542,42 & 110 & 50,38 & & & \\
\hline Toplam & 5542,42 & 110 & & & & \\
$* \mathrm{p}<0.05$ & & & & &
\end{tabular}


Analiz sonuçlarına göre okuduğu anlama testi kalıcılık puan ortalamaları bakımından gruplar arasında anlamlı farklılıklar $(\mathrm{p}=0.001)$ olduğu belirlenmiştir. Hangi gruplar arasında fark olduğunu belirlemek için de TUKEY HSD testine başvurulmuştur. Bu analiz sonucuna göre, okuduğunu anlama testi kalıcılık puan ortalamaları bakımından deney grubu 1 ile kontrol grubu arasinda $(\mathrm{p}=0.012<0.05)$ deney grubu 1 lehine; deney grubu 2 ile kontrol grubu arasinda $(\mathrm{p}=0.001<0.05)$ deney grubu 2 lehine, anlamlı farklılık olduğu görülmektedir.

Deney gruplarındaki öğrencilerin okuduğunu anlama kalıcılık testinden aldıkları puanların kontrol grubundaki öğrencilerin puanlarından anlamlı bir biçimde yüksek çıkması sonucu ile işe koşulan İTS ve TİÖD okuduğunu anlama stratejilerinin öğrencilerin hem okuduğunu anlama becerilerinin gelişmesine hem de öğrenilen bilgilerin yeterli bir biçimde hatırda kalmasına katkı sağladığını söylemek mümkündür.

\section{Sonuç ve Öneriler}

İTS ve TİÖD okuduğunu anlama stratejileri doğrultusunda işlenen Türkçe ders etkinliklerinin öğrencilerin okuduğunu anlama erişileri üzerinde olumlu bir etkiye sahip olduğu söylenebilir.

Deney grubu 1'de deneysel çalışmaların başlamasından bitimine kadar öğrenciler, okuduğunu anlama bakımından olumlu yönde bir gelişme göstermişlerdir. Soruların grup içinde tartışılarak yanıtının bulunması, öğrencilerin anlama becerilerinin daha da gelişmesine katkı sağlamıştır. İTS okuduğunu anlama stratejisini ilk defa yapılandıran Gauthier (2001), İTS doğrultusunda yapmış oldukları ders etkinliklerinin öğrenci- 
lerin derse ilgilerinin yanında okuduğunu anlama düzeylerini arttırdığını belirtmiştir. Croce'un (2007, s.2), araştırmasında iş birlikli öğrenmeyi sağlayan "öğrenci çalışma takımları”, "grup araştırmaları”, "jigsaw”, “yapısal yaklaşım”, “İTS” gibi öğrenme stratejilerinin ilköğretim 3. sınıf öğrencilerinin akademik başarıları üzerinde yeterli düzeyde etkili, ancak sosyal davranışları üzerinde az etkili olduğu saptanmıştır.

Rotruck’un (2001, s.2), “araştırmasında özellikle açıklayıcı metinlerde tahmin etme, inceleme, özetleme, örgütleme ve değerlendirme (TIOODD) işlevli bu tekniğin etkili bir okuma özelliğine sahip olduğu, aday öğretmenlerin yansıtıcı görüşleri, günlük kayıtları aracıllığıyla saptanmıştır. Englert ve Mariage'nin (1991), çalışmasında TïÖD okuduğunu anlama stratejisinin içinde yer alan etkinliklerin, öğrenme yetersizliği olan öğrencilerin açıklayıcı metinleri kavramalarını kolaylaştırdığını göstermiştir. Mariage'nin (1995) araştırmasında TíÖD okuduğunu anlama stratejisine dayandırılmış olan diyalogların kullanımında, düşük başarılı s1nıflarda öğretmenlerin konuşmanın çoğunu sürdürdüğü, ancak yüksek başarılı sınıflarda TİÖD’ün daha verimli geçtiği sonucuna ulaşılmıştır. TİÖD okuduğunu anlama stratejisi ile benzer bir çalışmada Lederer (2000) 128 ilköğretim öğrencisiyle yaptığı çalışmada karşılıklı öğretimin etkililiğini keşfetmiş ve deneysel grup öğrencilerinin okuduğunu anlama başarıları kontrol grubu öğrencilerinden daha yüksek olmuştur.

TİÖD okuduğunu anlama stratejisi kapsamında ele alınabilecek kavram haritası çıkarma, örgütleme ve özetleme yapma gibi stratejilerin okuduğunu anlama başarısı üzerindeki etkililiğine ilişkin yapılmış birçok çalışmada da bu stratejilerin işe koşulduğu deney grubu öğrencilerin ba- 
şarı testi puanlarının kontrol grubu öğrencilerinden daha yüksek olduğu görülmüştür. Örneğin; Ertem (2003), Chun Ou (2006), Görgen (1997), Chang, Sung ve Chen (2002) ve Belet (2005) tarafindan yapılan çalışmalarda öğrencilerin okuduğunu anlama becerilerinin geliştiği saptanmıştır.

Yukarıda verilmiş araştırmaların sonuçları, bu çalışmada bulduğumuz İTS ve TİÖD okuduğunu anlama stratejilerinin, ilköğretim birinci kademe 5. sınıf öğrencilerinin okuduğunu anlama başarı düzeylerini artırdığına ilişkin sonuçları desteklemektedir. İş birliği içinde tartışarak, sorgulayarak okuma parçalarına yönelik etkinlikleri yapmanın öğrencilerin okuduğunu anlama düzeylerinin artmasına katkı sağladığı söylenebilir. TİÖD okuduğunu anlama stratejisi doğrultusunda tahmin, inceleme, özetleme, örgütleme ve değerlendirme aşamaları hâlinde işlenen ders etkinliklerinin öğrencilerin okuduğunu anlamaya katkı sağlayan tahminde bulunma, tahminlerle hayal gücünü geliştirme, tahminlerini kavram haritaları, tablo veya görsellerle örgütleme, parçayı bir bütünlük içinde özetleme gibi birçok becerilerinin gelişmesine katkı sağladığı söylenebilir.

$\mathrm{Bu}$ araştırmanın bulgularını destekleyecek nitelikte daha önceden yapılmış birçok araştırma bulguları bulunmaktadır. Çörek (2006) ve Özçelik'in (2007) araştırmalarında iş birlikli öğrenmenin; Belet'in (2005) çalışmasında, not alma, özetleme ve kavram haritalarını kullanmanın; Çerçi’nin (2005) araştırmasında, bilgileri örgütleme, not alma, özetleme, kavram haritası çıkarmanın; Kaya'nın (2006) araştırmasında farklı öğrenme stratejilerinin öğrencilerin derslere ilişkin tutumları üzerinde olumlu etkilerinin olduğu saptanmıştır. 
Öğrencilerin okuduğunu anlama öz yeterlik algılarına ilişkin erişi ortalamaları bakımından deney grupları lehine anlamlı bir farklılık olduğu saptanmıştır. Bu sonuçtan hareketle, her iki deney grubunda işe koşulan stratejiler doğrultusunda işlenen derslerde öğrencilerin okuduğunu anlama öz yeterlik algılarının geliştiği söylenebilir.

Nelson (2003), Mason (2004), Durham (2006), Nelson ve Williamson (2006) gibi araştırmacıların yapmış oldukları çalışmalarda işe koşulmuş olan stratejilerin her biri birer karma strateji olan İTS ve TİÖD okuduğunu anlama stratejileriyle ilişkili veya onların işleniş aşamalarından birinin işe koşulduğu stratejilerdir. Bu çalışmalarda işe koşulan stratejilerin her birinin öğrencilerin okuduğunu anlama öz yeterlik algıları üzerinde olumlu etkilerinin olduğu belirlenmiştir.

İşe koşulan İTS ve TİÖD okuduğunu anlama stratejileri, öğrencilerin hem okuduğunu anlama becerilerinin gelişmesine hem de öğrenilen bilgilerin yeterli bir biçimde hatırda kalmasına katkı sağlamıştır. İTS ve TİÖD okuduğunu anlama stratejilerinin öğrencilerin bilişsel ve duyuşsal öğrenmeleri üzerindeki etkilerini belirlemek üzere yapılmış olan bu araştırmadan elde edilen sonuçlardan hareketle, aşağıdaki önerilerde bulunulabilir:

Öğrencilerin hem bilişsel hem de duyuşsal öğrenmelerinin anlamlı ve istenen bir biçimde geliştirilebilmesi için, Türkçe ders etkinliklerinde iş birlikli grup çalışmalarına, soru-cevap ve tartışma etkinliklerine yer verilmelidir. Türkçe ders etkinliklerinde öğrenciler parçayı okumaya başlamadan önce okuma parçasıyla birlikte verilmiş resimlere ve görsellere 
bakarak parçanın konusunu tahmin etmeye teşvik edilmelidir. Okuma parçaları okunmadan önce, öğrencilerin hayal güçlerini zenginleştirici etkinlikler yapılmalıdır. Türkçe ders etkinliklerinde öğrenciler metne yönelik kavramalarını kavram haritalarıyla, görsel şekil ve tablolarla örgütlemeye yönlendirilmelidir. Öğrenciler, okuma parçalarını anlamaya yönelik etkinlikler sonunda kavramayı pekiştirici sorular oluşturmaya ve yanıtlamaya yönlendirilmelidir. Öğrencilerde oluşması hedeflenen anlamlı öğrenme için Türkçe dersinin dışında fen ve teknoloji öğretimi, hayat bilgisi ve sosyal bilgiler öğretimi gibi derslerde de öğrencileri konuya ilişkin özetleme, gruplama ve örgütleme yapmaya teşvik edilmelidir. İTS ve TİÖD okuduğunu anlama stratejilerine Türkçe dersi öğretim programında önerilen stratejiler arasında yer verilmelidir. Türkçe ders kitaplarındaki etkinlikler İTS ve TIÖD okuduğunu anlama stratejileri dikkate alınarak yeniden düzenlenmelidir. Sınıf öğretmenleri ile branş öğretmenleri, okuduğunu anlama stratejileri ve özellikle İTS ve TİÖD okuduğunu anlama stratejileri konusunda bilgilendirilmelidir. Bunun için hizmet içi eğitim seminerleri düzenlenebilir. İTS ve TİÖD okuduğunu anlama stratejilerinin Türkçe dersi dışında hayat bilgisi öğretimi, sosyal bilgiler öğretimi, fen ve teknoloji öğretimi derslerinde de öğrencilerin bilişsel ve duyuşsal öğrenmeleri üzerindeki etkileri incelenebilir.

\section{Kaynakça}

Akyol, H. (2005). Türkçe ilk okuma yazma öğretimi. Ankara: Pegema Yayınları. 
Belet, Ş. D. (2005). Öğrenme stratejilerinin okuduğunu anlama ve yazma becerileri ile Türkçe dersine ilişkin tutumlara etkisi. Yayımlanmamış doktora tezi, Anadolu Üniversitesi Eğitim Bilimleri Enstitüsü.

Bender, W. N. ve Larkin, M. J. (2003). Reading strategies for elementary students with learning difficulties. Georgia: Corwin Press. 13.01.2008, 18:56, www.corwinpress.com.

Block, C.C. (2004). Teaching comprehension. New York: Pearson Education Inc.

Brown, A.L. ve Palincsar, A. S. (1985). Reciprocal teaching of comprehension strategies: a natural history on one program for enhancing learning. 21.02.2008, 20:10, Technical Report No.334, Reading and Communication Skills. Eric: Ed257046.

Büyüköztürk, Ş. (2004), Sosyal bilimler için veri analizi el kitabı. Ankara: Pegema Yayınları.

Chang, K., Sung, Y. ve Chen, I. (2002), The effect of concept mapping to enhance text comprehension and summarization. The Journal of Experimental Education, 71, 1-13. 18.02.2008, 21:14, http://www.proquestcompany.com.

Chun Ou, F. (2006). The effects of the summarization strategy on reading comprehension of non-proficient Taiwanese university EFL learners. Yayınlanmamış doktora tezi, The University of Kansas. 16.05.2008, 12.34, http://www.proquestcompany.com. 
Croce, L. (2007). The effect of cooperative learning on elementary school students' academic achievement and pro-social behavior. Yayınlanmamış yüksek lisans tezi, Cortland: The State University College, 14.05.2008, 12:36. http://www.proquestcompany.com.

Çakıc1, D. (2005). Ön örgütleyicilerin okumaya yönelik tutum ve okuduğunu anlama üzerindeki etkileri. Yayımlanmamış doktora tezi, Dokuz Eylül Üniversitesi Eğitim Bilimleri Enstitüsü.

Çerçi, A. (2005). Türkçe öğretiminde öğrenmeyi öğrenme stratejilerinin ögrencilerin anlama düzeylerine etkisi. Yayınlanmamış yüksek lisans tezi, Selçuk Üniversitesi Sosyal Bilimler Enstitüsü.

Çörek, D. (2006). İşbirlikli öğrenmenin Türkçe dersine ilişkin başarı ve derse yönelik tutum üzerindeki etkileri. Yayınlanmamış yüksek lisans tezi, Dokuz Eylül Üniversitesi Eğitim Bilimleri Enstitüsü.

Daly, E.J. ve Chafouleas, S. Skinner, C.H. (2005). Interventions for reading problems. Newyork : The Guilford Press.

Demirel, Ö. ve Şahinel, M. (2006). Türkçe ve sınıf öğretmenleri için Türkçe öğretimi. Ankara: Pegema Yayınları.

Durham, G. B. (2006). The effectiveness of the BICUM study reading instructional strategy on reading comprehension and self-efficacy levels of first years first semester students enrolled in a three credit college developmental reading and study skill course. Yayınlanmamış doktora tezi, The University of Duquesne. 16.05.2008, 12:24, http://www.proquestcompany.com. 
Englert, C. S. ve Mariage, T. V. (1991). Making students partners in the comprehension process: organizing the reading "POSSE". Journal of Learning Disability Quarterly, 14(2). 123-138. 17.04.2008; 18:23, http.//jstor.org/journals/07319487html.

Ertem, Ş. (2003). Müzik bölümü temel piyano eğitiminde öğrenme stratejilerinin kullanılma durumları ve örgütleme stratejisinin etkililik düzeyi. Yayımlanmamış doktora tezi, Gazi Üniversitesi Eğitim Bilimleri Enstitüsü.

Gambrell, L. B. (1996). What research reveals about discussion. Fostering Engaged Reading içinde (25-38). Newark, De: International Reading Association.

Gauthier, L. R. (2001). Coop-Dis-Q: A reading comprehension strategy. Intervention in School and Clinic, 36(4). 04.05.2007, 19:24, Issn:10534512 http:finder articles.com/p/articles.

Görgen, İ. (1997). Özetleme ve bilgi haritası oluşturma ögretiminin bilgilendirici bir metni ögrenme ve hatırlama düzeyine etkisi. Yayımlanmamış doktora tezi, Hacettepe Üniversitesi Sosyal Bilimler Enstitüsü.

Güneş, F. (2004). Okuma yazma öğretimi ve beyin teknolojisi, Ankara: Ocak Yayınları.

Johnson, D.W., Johnson, R.T. ve Holubee, E.J. (1994). The new circles of learning: cooperation in the classroom and school, Alexandria: Va Association for Supervision and Curriculum Development. 
Kalayc1, Ş. (Ed.). (2005). SPSS uygulamalı çok değişkenli istatistik teknikleri. Ankara: Asil Yayın Dağıtım.

Kantemir, E. (1995). Yazılı ve sözlü anlatım. Ankara: Engin Yayınları.

Kaptan, S. (1998). Bilimsel araştırma ve istatistik teknikleri. Ankara: Tekışık Matbaası.

Karasar, N. (2005). Bilimsel araştırma yöntemi. Ankara: Nobel Yayınevi.

Kaya, F. (2006). İlköğretim dördüncü sınıf Türkçe dersinde bazı öğrenme stratejilerinin tutum ve okuduğunu anlamaya etkisi. Yayımlanmamış yüksek lisans tezi, Mustafa Kemal Üniversitesi, Sosyal Bilimler Enstitüsü.

Kent, A. M. (2002). An evaluation of the reading comprehension strategies module of the Alabama reading initiative with five elementary schools in southwest Alabama. Yayımlanmamıs doktora tezi, The University of South Alabama. 15.05.2008, 17:55, http://www.proquestcompany.com.

Lederer, J. M. (2000). Reciprocal teaching of social studies in inclusive elementary classrooms. Journal of Learning Disabilities, 33, 91106.

Mariage, T. V. (1995). Why students learn: the nature of teacher talk during reading. Learning Disability Quarterly, 18 (3), 214-234. 21.03.2008, 13:45, www.jstor.org. 
Mason, L. H. (2004). Explicit self regulation strategy development versus reciprocal questioning: effects on expository reading comprehension among struggling readers. Journal of Educational Psychology, 96, 283-296.

Nelson, E. (2003). The effect of metacognitive strategy instruction on fifth grade comprehension of expository text, Yayımlanmamıs doktora tezi, University of Bridgeport. 15.05.2008, 14:07, http://www.proquestcompany.com.

Nelson, J. M. ve Williamson, G. M. (2006). The impact of explicit, selfregulatory reading comprehension strategy instruction on the reading specific self-efficacy, attributions and affect of students with reading disabilities. Learning Disability Quarterly, 29, 213-231. 15.05.2008, 14:33, http://www.proquestcompany.com.

Özçelik, A. (2007). İşbirliğine dayalı öğrenmenin fen bilgisi dersinde başarı, tutum ve kalıcı öğrenmeye etkisi. Yayımlanmamış yüksek lisans tezi, Osmangazi Üniversitesi Fen Bilimleri Enstitüsü.

Palincsar, A.S. ve Brown, A. L. (1984). Reciprocal teaching of comprehension-fostering and comprehension monitoring activities. Cognition and Instruction, 1, 117-175.

Piloneita, P. (2006). Genre and comprehension strategies presented in elementary basal reading programs: a content analysis, Yayımlanmamış doktora tezi, University of Miami. 15.05.2008, 14:14, http://www.proquestcompany.com. 
Pressley, M. (2002). Comprehension strategies instruction: a turn of the century status report, Comprehension Instruction Research Based Best Practices içinde. London: Guilford Press.

Radoyevic, N. (2006). Exploring the use of effective learning strategies to increase students' reading comprehension and test taking skills. Yayımlanmamış yüksek lisans tezi, The Brock University, 15.05.2008,14:20, http://www.proquestcompany.com.

Rose, D.S., Parks, M., Androes, K. ve McMahon, S. D. (2000). Imagery based learning: improved elementary students reading comprehension with drama techniques. The Journal of Educational Research, 94(1), 15.05.2008, 10:21, http://www.proquestcompany.com.

Rotruck, K. H. (2001). A study of the effects of the posse technique on the perceptions of pre-service teachers in teaching learning disabled students. Yayımlanmamış doktora tezi, West Virginia University. 21.04.2008, 16:35, http://www.proquestcompany.com.

Strother, D.B. (1989). Developing Thinking Skills Through Questioning. Phi Delta Kappan, 71, 324-327.

Stroud, C. K. (2006). Development of the school motivation and learning strategies inventory, Yayımlanmamış doktora tezi, A\&M University. 15.05.2008 17:21, http://www.proquestcompany.com.

Şengül, M. ve Yalçın, S. K. (2004). Okuma ve anlama becerilerinin geliştirilmesine yönelik olarak hazırlanan bir model önerisi. Millî Eğitim Dergisi, 164. 16.04.2008, 17:21. 
http://dhgm.meb.gov.tr/yayimlar/dergiler/Milli_Egitim_Dergisi/16 4/sengul.htm

Turgut, F. (1984). Eğitimde ölçme ve değerlendirme metotları. Ankara: Saydam Yayıncılık.

Yaman, B. (1999). Birleştirilmiş kubaşık okuma ve yazma tekniğinin temel eğitim beşinci sinıf ögrencilerinin Türkçe dersinde okuduğunu ve dinlediğini anlamaya yönelik akademik başarlları ile Türkçe dersine ilişkin tutumları üzerindeki etkisi. Yayımlanmamış yüksek lisans tezi, Çukurova Üniversitesi Sosyal Bilimler Enstitüsü.

Wellington, J. ve Osborne, J. (2001). Language and literacy in science education. Buckingham, Philadelphia: Open University Press. 